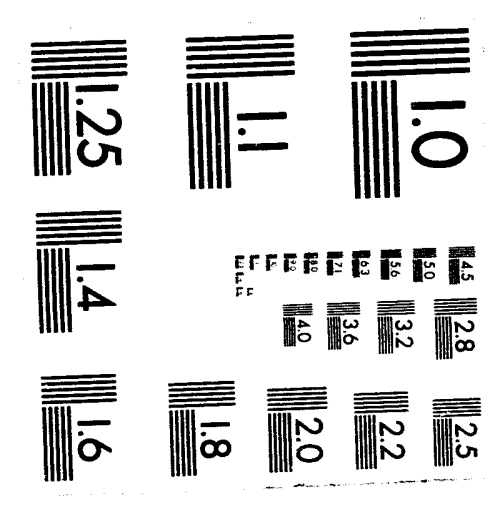



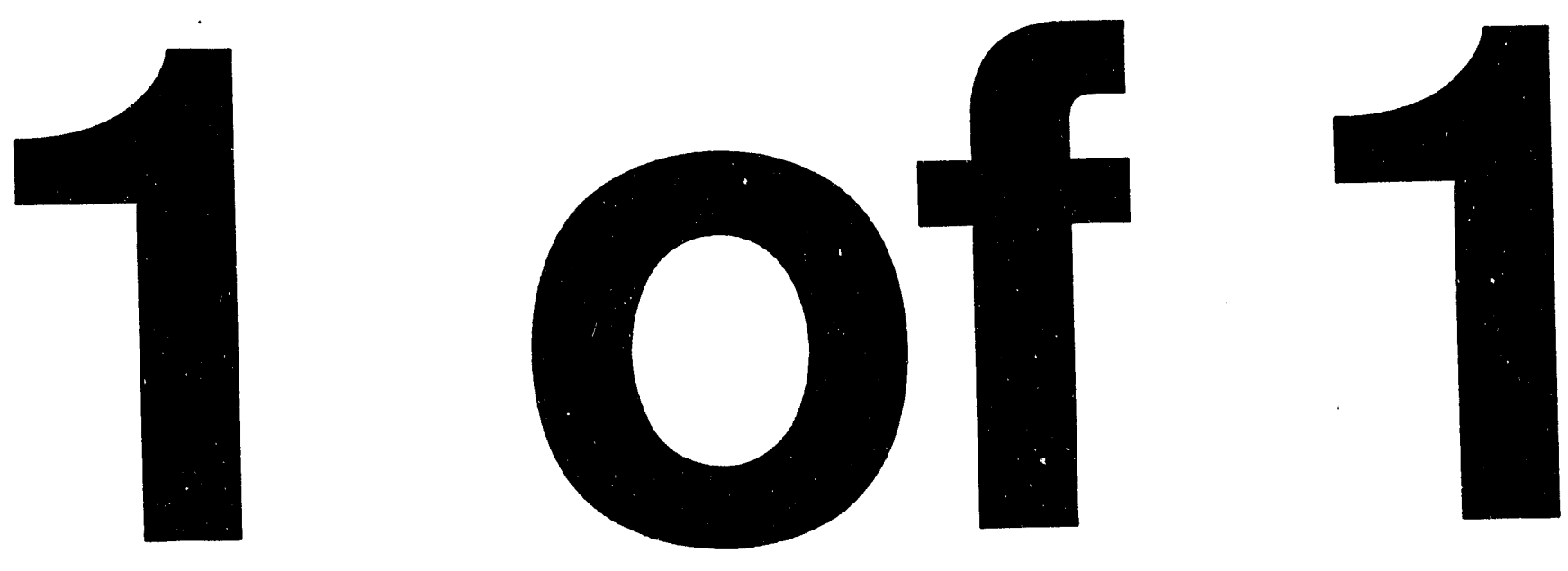


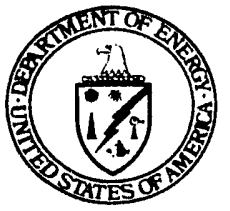

\section{CERCLA Reporting Requirements, DOE Occurrence Reporting, and the DOE Emergency Management System}

BACKGROUND: The Emergency Management System (EMS) provides a structure for reporting and processing operations information related to DOE owned/operated facllities. Hezardous Substance (HS) releases are subject to reporting requirements under the EMS as well as under the Comprehensive Environmental Response, Compensation, and Liablity Act (CERCLA). CERCLA requires reporting of HS releases Into the environment in amounts greater than or equal to Reportable Quantitles (RQs). This information Brief elaborates on earlier CERCLA reporting and response process Information Briefs by providing a general explanation of these CERCLA or EMS requirements, procedures, and events as they pertain to releases of HS's af DOE faclitiles.

STATUTES: $\quad$ CERCLA Section 103.

REGULATIONS: 40 CFR 302.6 (National Contingency Plan (NCP))

REFERENCES: 1. DOE Order 5400.4 - "Comprehensive Environmental Response, Compensation, and Liability Act Requirements"; DOE Order 5400.5 - "Radiation Protection of the Public and the Environment"; DOE Order 5000.3B - "Occurrence Reporting and Procesesing of Operations Information"; DOE Order 5500.1B - "Emergency Management System"; DOE Order 5500.2B - "Emergency Categorles, Classes, and Notification and Reporting Requirements"; DOE Order 5500.3A - "Planning and Preparedness for Operational Emergencles"; and DOE Order 5500.10 - "Emergency Readiness Assurance Program."

2. "Reporting Releases of Hazardous Substances under CERCLA \& EPCRA" Information Brief (EH231-001/0490).

3. EH-231 Memorandum, January 10, 1990; "Final Reportable Quantitles of Radionuclides and Rules for Reporting Releases of Radionuclides under CERCLA."

4. S-3 (DP-9) Memorandum, July 19, 1990; "Emergency Managément and Off-slte Notification."

5. "Guidance for Federal Facilites on Release Notification Requirements under CERCLA and SARA Title III," (EPA 9360-7.06/EH-231 Memorandum, March 29, 1991).

6. "Reportable Quantity Adjustments for Lead Metal, Lead Compounds, Lead-containing Hazardous Wastes, and Methyl lsocynate - Reportable Quantitles Adjustments; Final Rule lesued," EH-231 Regulatory Bulletin, September 15, 1993.

What are the CERCLA requirements for reporting a hazardous substance release at DOE facilities?

Under CERCLA, reportable quantities have been specified for each HS listed in 40 CFR 302.4. RQs range between 1 and 5,000 pounds for a non-radionuclide HS or between .001 and 1,000 curies for radionuclide HSs (except for uranyl acetate and uranyl nitrate, which are also expressed in pounds), released into the environment during a 24-hour period. If, within any 24-hour period, there is an unpermitted release of an HS in an amount that meets or exceeds an $R Q$, the facility manager must immediately report the release to the National Response Center at (800) 4248802 or, in the Washington D.C. area, (202) 267-2675. The 24-hour period applies to measuring the amount released, not to the period within which the release must be reported.

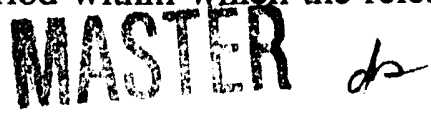

DISTIIBUTION OF THIS DOCUMENT IS UMUMUITS 


\section{DISCLAIMER}

This report was prepared as an account of work sponsored by an agency of the United States Government. Neither the United States Government nor any agency thereof, nor any of their employees, makes any warranty, express or implied, or assumes any legal liability or responsibility for the accuracy, completeness, or usefulness of any information, apparatus, product, or process disclosed, or represents that its use would not infringe privately owned rights. Reference herein to any specific commercial product, process, or service by trade name, trademark, manufacturer, or otherwise does not necessarily constitute or imply its endorsement, recommendation, or favoring by the United States Government or any agency thereof. The views and opinions of authors expressed herein do not necessarily state or reflect those of the United States Government or any agency thereof. 
When an HS is released at a DOE facility, who is responsible for satisfying the reporting requirements?

In accordance with Section 103 of CERCLA and 40 CFR 302.6, the person in charge of a DOE facility is responsible for reporting a release of an HS. Similarly, DOE Orders 5000.3B, 5500.1B, and 5500.2B require that the facility manager to promptly report HS releases that are categorized as reportable occurrences to DOE and all applicable Federal, State, local, and tribal authorities. The facility manager at DOEowned, contractor-operated facilities will be a contractor. Therefore, in accordance with a policy memorandum issued by the Under Secretary, the contractor managing the facility from which an HS has been released will be responsible for complying with the reporting requirements unless DOE has formally reclaimed that responsibility.

At Power Administrations, which are owned and operated by DOE employees, the facility manager will be a DOE employee. Thus, releases from Power Administrations will be reported by DOE employees.

\section{What other reporting requirements must DOE facilities satisfy when there is a release of a CERCLA HS?}

In accordance with DOE Order 5000.3B, releases of HSs are categorized as reportable occurrences if the amounts released equal or exceed the RQs defined in 40 CFR 302. In the event of a reportable occurrence, DOE requires the timely identification, categorization, notification, and reporting of the occurrence to DOE and contractor management. Additionally, if a reportable occurrence can be categorized as an emergency, DOE Order $5500.2 \mathrm{~B}$ requires the facility manager to notify all appropriate Federal, State, tribal, and local authorities within 15 minutes of categorizing the release as an emergency. Following notification, an Emergency Management Team (EMT) is formed to evaluate and respond to the emergency.

\section{How are the CERCLA release reporting requirements addressed by DOE's Emergency Management System (EMS)?}

Established by DOE Order 5500.1B, DOE's EMS, while not specifically designed to address the notification and reporting requirements of environmental regulations, formalizes those requirements for the DOE complex by stating that it is departmental policy to comply with all reporting requirements. The EMS provides the framework for DOE planning, preparedness, notification, and response activities that must be conducted at facilities, field offices, and DOE Headquarters (HQ).

\section{Under the EMS, is an HS release always considered to be an emergency?}

No, release of an HS is not always categorized as an emergency. Under DOE Order 5000.3B, HS releases may be categorized as an emergency, unusual occurrences, or off-normal occurrences, depending on the severity of the release. If an RQ of an HS is released into the environment, the release is categorized as either an emergency or an unusual occurrence. Under the EMS, a release of an RQ of an HS is considered an emergency only if the release results in or could potentially result in significant off-site consequences.

HS releases that meet or exceed the RQ threshold but will not potentially result in significant on-site or off-site consequences are classified as unusual occurrences. Releases of amounts less than an RQ that could not potentially cause significant consequences either on-site or off-site are classified as off-normal occurrences. Quantification of the amount of HS released is a part of the off-normal or unusual occurrence declaration under DOE Order 5000.3B, which specifies the reporting requirements and categorizations for these types of events. 
What are the various relationships between DOE officials (i.e., Headquarters and field elements) and their contractors for reporting releases of HSs per CERCLA, DOE's Occurrence Reporting System, and the EMS?

The EMS delineates a three-tiered organizational approach to operational emergency response. This approach follows the line management chain within DOE. Responsibility begins at the facility level, rises through the cognizant DOE field element, and culminates at the cognizant HQ Program Office.

At the facility level, the facility manager is responsible for:

- initially identifying and categorizing the event,

- immediately notifying the National Response Center of the release,

- promptly notifying Federal, State, tribal, and local authorities offsite, and

- informing DOE line management about all aspects of the response to the release. For oral notifications, the DOE HQ Emergency $O p$ erations $C$ enter (EOC) and the cognizant field element both receive simultaneous notification of emergencies from the facility manager.

The head of the cognizant DOE field element is responsible for assuring that all of the notifications listed above are made. If the facility manager does not provide the notifications (i.e., the situation is not covered by the contractor's or the DOE field element's notification process), or if DOE has retained that authority (per the Under Secretary's memo of July 19, 1990), the DOE field element must make the emergency notifications. The field element also provides additional technical assistance and support, predesignates an On-Scene Coordinator for responses under the National Contingency Plan, and ensures that response actions are coordinated with other participating Federal, State, tribal, and local authorities.
In addition, the DOE field element must oversee the local investigation and closeout of the occurrence in coordination with the HQ Program Manager (PM). The PM is the individual at HQ who is responsible for the facility and who has significant authority to provide technical direction to the facility contractors through the DOE field element.

At the HQlevel, DOEOrder $5500.1 \mathrm{~B}$ requires that an emergency management team under the cognizance of the lead Program Secretarial Officer (PSO):

- monitor actions taken by the facility and field element emergency response organizations,

- manage requests for emergency response assistance to be provided from other DOE elements and/or other Federal agencies,

- provide interface with the White House, Congress, and national-level agencies, and

- coordinate public information activities.

The HQPSO reviews and approves all facility and field element emergency plans in coordination with the Director of Emergency Operations.

The HQ EOC serves as the focal point for all emergency notifications and reports. It receives, records, verifies, and disseminates emergency information to Congressional offices, the White House Situation Room, and other Federal agencies, as well as to appropriate HQ elements and program office emergency points of contact such as the Program Manager (PM). The EOC is operated 24-hours per day.

\section{What categories of releases at DOE facilities are exempt from the CERCLA reporting requirements?}

The regulations in 40 CFR 302.3 specifically exempt the following releases from the CERCLA reporting requirements: 
- release of source, by-product, or special nuclear material from a nuclear incident subject to requirements of the Nuclear Regulatory Commission for financial protection under Section 170 of the Atomic Energy Act of 1954 (AEA),

- releases resulting in exposure to persons solely within a workplace (releases occurring in a closed space with no emissions to the ambient environment),

- federally permitted releases (i.e., releases of source, special nuclear, or byproduct material, as those terms are defined in the AEA, in compliance with a legally enforceable license, permit, regulation, or order issued pursuant to the AEA; and discharges covered by a National Pollutant Discharge Elimination System permit, permit application, or permit administrative record),

- emissions from the engine exhaust of a motor vehicle, rolling stock, aircraft, vessel, or pipeline pumping station engine, and

- continuous releases, stable in quantity and rate, for which notice was given and there was a period sufficient to establish the continuity, quantity, and regularity of such release.

Is an accidental radionuclide release that is below the fenceline radiation limit, as specified by DOE Order 5400.5, considered a Federally permitted release that is exempt from CERCLA reporting?

If a DOE activity results in a radionuclide release below the fenceline radiation limits, it is considered to be a Federally permitted release if it does not exceed the limits specified in DOE Order 5400.5 and if the facility is in compliance with the DOE policies, guidelines, and requirements specified in the DOE Orders. The release is not considered a Federally permitted release if it is the result of an activity that is determined to be either accidental or a poor management practice. For example, a release that occurs as a result of leaking drums or a valve failing due to improper maintenance is not considered a Federally permitted release, even if the fenceline radiation limits are not exceeded as a result of the release.

In light of the Fertilizer Institute vs. EPA court decision (CA DC, No. 89-1404, 6/11/91), does stockpiling or placement of radioactive wastes or products that may release radionuclides to the environment constitute a release under CERCLA?

Under CERCLA, the phrase "release into the environment" has been interpreted by EPA to include any activity that involves placement of an HS into any unenclosed containment structure from which the HS is exposed to the environment (54 FR 22526). This interpretation was rejected in the Fertilizer Institute court decision wherein the U.S. Court of Appeals for the DC Circuit ruled that non-volatile materials being stored in uncovered piles were not emitting HS into the environment (i.e., did not enter the atmosphere).

According to this court decision, the storage of radioactive waste or products in uncovered piles would not constitute a release under CERCLA if the radionuclides were being exposed to, but not entering into, environmental media. To be reportable, the HS must undergo volatilization or escape into the air, or migrate into the surrounding water or soil. Furthermore, the emission of radiation from radionuclides, apart from the release of the radionuclides themselves, does not constitute a release under CERCLA (54 FR 22526).

Questions of policy or questions requiring policy decisions will not be addressed within EH-231 Information Briefs unless that policy has already been established through appropriate documentation. Please refer any questions concerning the subject material covered in this Information Brief to Richard Dailey, EH-231, (202) 586-7117. 

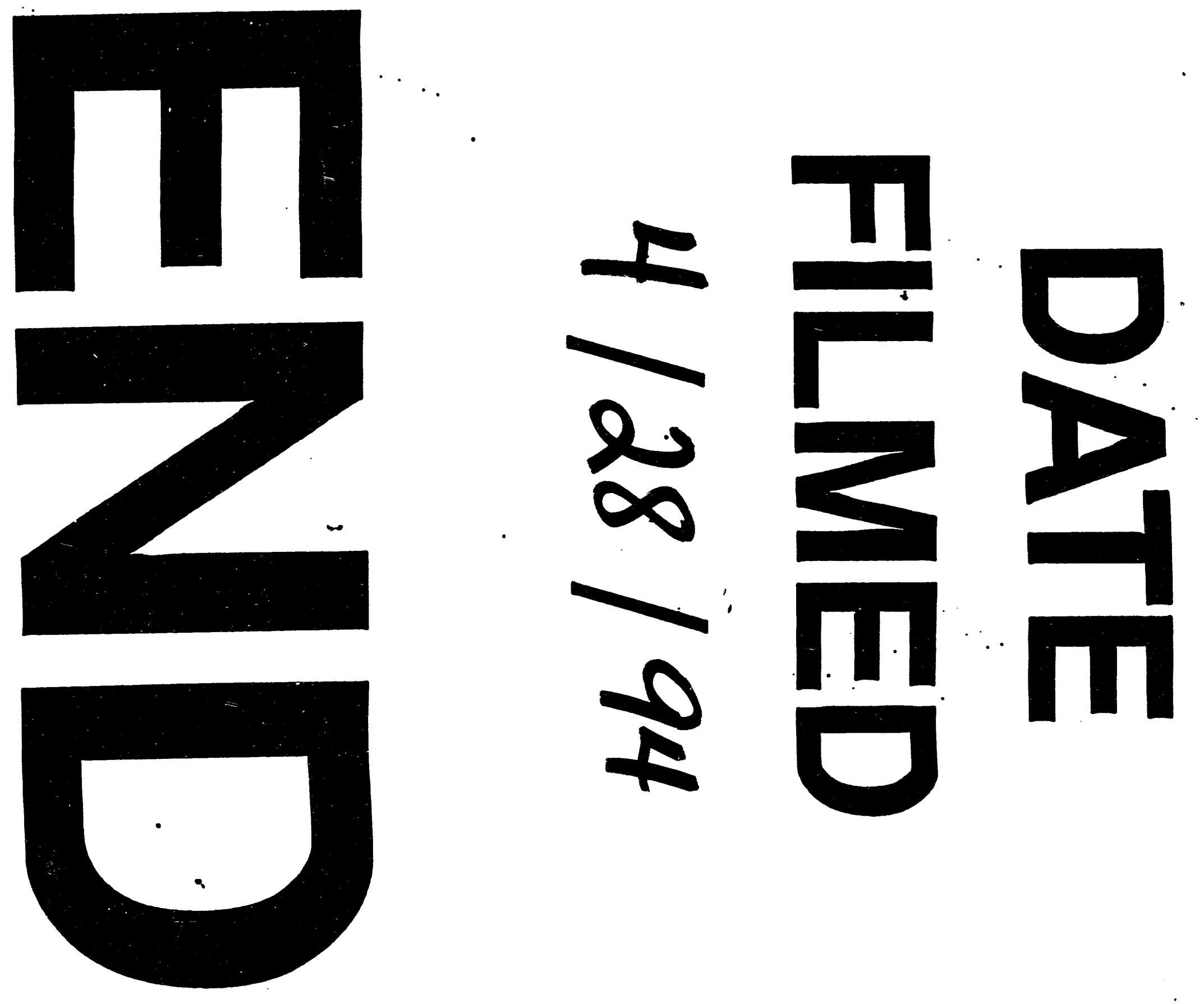


$$
\text { - }
$$

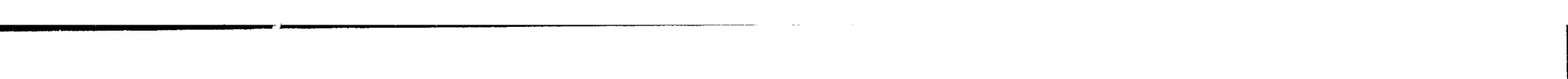

